\title{
Hardy's View on Love and Marriage
}

\author{
Xiang Xu \\ College of Foreign Language \\ Qingdao University of Science and Technology \\ Qingdao 266061, China \\ E-mail: stephenxu10@163.com
}

\begin{abstract}
This paper ranges widely to track of the evolution of Hardy's view on love and marriage, and analyzes two reasons why this unique view developed: one is Nature; another is Time.

Keywords: Hardy, View, Evolution, Reason

\section{Introduction}

Hardy's life overstretches two centuries. He is a giant standing on the joint of the Victorian Era and the twentieth century. He witnesses the existence and disappearance of the beautiful idyllic life on Wessex land, undergoes the impact between the patriarchy and the new capitalism, and confirms the course that capitalism declines from advancement into corruption. From a youngster without any experience to a rebel who makes a display of his opposing abilities to society, Hardy goes through too much change together with English society. This unusual experience also impels the evolution of his view on love and marriage.
\end{abstract}

\section{The Development and Evolution of Hardy's view on Love and Marriage}

\subsection{Songs for the Pastoral Love in Wessex}

In the middle of the nineteenth century, Bockhampton, on the seaside of Dorset County in the southwest of England, was a beautiful village with pastoral landscape. It is far from the world of industry and maintains ancient traditions with a presentation of quiet grace and tranquility. Growing up in this natural and picturesque environment, he was much influenced by the traditional life style and the cultural atmosphere and nurtured by the country people's virtues of diligence, simplicity, kindness and unselfishness. Since childhood Hardy had formed a kind of thought and mood of love for nature as well as for these people. In his early novels, he praises his birthplace in a style full of romantic color and he extols the excellent virtue of these country people with his heart and soul. This is also Hardy's most important theme in his earlier novels.

In the long span of his writing period during the early 1870's, Hardy sings the praises of the perfect and romantic love and marriage to a considerable extent because of his having been sentimentally attached to his homeland and his zeal for the simple country life. Far from the Madding Crowd depicts the ideal Wessex love life. In this novel Hardy praises the beautiful love through much rough experience between Oak and Bathsheba. Hardy makes some comments when he mentions this novel, "This combination, this friendship between two who have the same interests, was made by chasing the same aim, unfortunately, it is rarely attached to the love of males and females, for they commute not in their working time, but in their playing time. However, only in this happy place where it may happen, this total friendship could prove it is love, strong like death, no fire can put off, no flood can drown. Comparably, the one usually called desire disappears at once like steam."(H. Lea, 34) From these words we can distinctly perceive Hardy's high praise for this love.

However, not all the readers treat Far from the Madding Crowd as a pure comedy, despite the fact that the story ends in a happy reunion, but Hardy portrays Bathsheba, the female protagonist with plenty of tragic factors. Bathsheba is a beautiful, zealous and ambitious girl who longs for and goes after freedom and has a great idea, but the weakness hidden in her character, such as vainglory, indiscreet activities, and so on, leads her to tragedy. So, although Bathsheba often seems self-confident and decisive and daring to do anything she has promised, she still has to do everything according to the rules she herself, others and the society have set consciously or unconsciously.

Far from the Madding Crowd reaches to the peak of Hardy's pastoral novels, but just at this moment, the more Hardy senses the life of reality, the more life tragedies he notices in patriarchal society which used to be serene and simple--the decline of traditional order, the impoverished condition of small-scale peasant economy, the attack of evil power, and the frustration of pure and honest country people, etc. At last, his eyes which used to be longing for sunshine and flower turn rather dim and his songs of aspiring sweet tomorrow disappear. The appearance of Far from the Madding Crowd 
still continues to use an old love story which is about the feeling entanglement of a certain males and females. However, the difference from Hardy's former novels such as Under the Greenwood Tree, A Pair of Blue Eyes, etc, is apparent. Although from this story one might hear the pastoral songs and smell the expressive romanticism, in Weatherbury Farm there could not be miracles any more--it is really far from the madding crowd, but tragedies still takes place, just like in the crowded metropolis. The novel ends in a perfect love reunion, but the atmosphere is pervaded with tragedy throughout the novel. The readers can feel all kinds of tragic factors. The conflict between the character and the environment displays its talent for the first time. Predestination and the idea of tragedy also have an inkling, and many sides, such as the tragedy connotation, the art style and the character figure, etc, are all the beginning of novels full of tragic consciousness.

\subsection{Appreciation to the New Capitalism}

When Hardy amplifies his fine artistic imagination to sing high praises for his lovely patriarchal society, capitalism in Britain gradually developed itself. From the end of the 1870's to the middle of the 1880 's, following the absolute superiority of capitalism in politics and economy, the power of the capitalist class permeates into the country quickly. The patriarchy in Wessex is shaken unexpectedly, and many love and marriage tragedies are performed on the life stage. Although Hardy still stands for the conventional patriarchal view at that time and makes these love tragedies so miserable and reveals endless sympathy and pity, as an austere author of realism, he never attempts to paint pretty pictures about the reality in his works. He always faithfully details the certainty of love tragedy.

The thoughts, feelings and experiences of the protagonists in Hardy's novels are all superior to the people around them contemporaneously. In Jude the Obscure, Jude and Sue sigh when they are in passionate love. They wish they could be born fifty years later. Hardy thinks if fifty years later Jude and Sue live together on the basis of true love, it will accord with the tide of time and be accepted by the public opinion. Therefore, to the society of that time the love of the protagonists is rebellious. Their love tragedy is a contradiction between their respective pursuit for ideal, love and marriage and a failure in attaining it. Eustacia, the heroine of The Return of the Native expresses her strong will and fervent wish of pursuing love happiness, but this will and wish run contrary to the deep-rooted traditional view of love and marriage of the people in Egdon Heath. Hardy presents this woman with an advanced mind. When she stays with those people who have the conventional mind, her activity seems so unusual. Her unconventional nature is the origin of this mind. In Eustacia's eyes, Egdon Heath is a prison that puts fetters on her love happiness, so she often prays to God to bestow a great love upon her. The heath is a symbol of the old tradition. It demands its people to act in line with the traditional custom and morality, so it cannot bestow love and comfort on Eustacia. Eustacia attempts not to obey the traditional love and marriage under the background of Egdon Heath in Wessex, so she has to be an immolator of normal love view and choose death. In The Mayor of Casterbridge, Hardy also describes the love tragedy of Henchard. As Henchard's view of love still represents the tradition of patriarchal society in Casterbridge, he cannot compete with the new capitalist class who has fresh view of marriage, so his tragedy takes place. In this novel Hardy's view is that the love and marriage of new capitalist class will eventually defeat the old and decayed love and marriage of patriarchal society.

Eustacia is typical of Hardy's characterization during this period, and is at once a much disputed figure. One view is that she is a character of Flesh because of her frivolity, dissoluteness and vainglory. This conclusion is drawn from her character and experience: Eustacia admires the pragmatism and the hedonism, and builds fantasies for the high society's showy life of the capitalist class. As she comes from another big city, she is unable to adapt to life here upon her arrival. And between her character and both the natural and the societal environments, a conflict grows up inevitably, even the people of the heath curse at her as being a witch. Besides, Eustacia's love is so easy and indiscreet, and void of morality. She keeps dating with a hypocrite called Wildeve secretly. She knows it is not true love, but still plays this game that means nothing. Later, when she hears that the young dealer Clym is coming back from Paris, her heart of pursuing vainglory beats hard again. In her opinion Clym is sure to know everything about Paris and he can bring her good luck, so before they meet she has been in love with him. She dreams when they are married, she could persuade Clym to go back to Paris again. However, the reason why Clym returns is just he is tired of city life and decides to spend his life nestling in nature's arms placidly. The strong disappointment makes Eustacia go back to Wildeve again after marriage and continues to date with him secretly. Once, when Wildeve is in her house, her mother-in-law comes to pay a visit, Eustacia does not answer the door. The old woman is killed by a wild cobra. After a big quarrel with her husband, she plans to elope with Wildeve in order to escape from the heath and get to Paris she longs for, but unfortunately both of them are drowned on their way. From her story one can concludes that Eustacia's tragedy is due to her dissolute character, weak view of morality and strong vainglory. She has only herself to blame.

However, on the contrary, another view has it that Eustacia is a brave female who struggles against society for her freedom and happiness. To stress her dissoluteness and vainglory is because they ignore her positive side of opposing the old tradition and pursuing human nature which should be praised. According to this view, under such a close, conservative and backward condition in Egdon Heath, Eustacia's pursuit and rebellion are only too natural. Eustacia is 
active, fond of adventure and fantasy, and she likes to pursue exciting life. Such a woman is sure to be different from the rigidity and poverty of the heath, so she feels uncomfortable and oppressed. Her only purpose is to get away from this environment which has prevented her from developing, and spend her life in Paris, her ideal heaven. Of course, it is a pity for her to put her ideal on the showy and vainglorious life. But from the view of humanitarianism, it should be praised because she apposes the oppressing environment and dares to pursue a happy life.

\subsection{Opposition against the Decayed Capitalism}

In the late 1890 's, with the development of the new society, Hardy finds that the marriage of the new capitalist class changes from that of the former, maybe more advanced view, to the present, possibly more backward consciousness. At the time when the new-rising capitalism intrudes into the Wessex country, in order to conquer the traditional and conservative patriarchy, their view of marriage tries to conform to the development of history and respect the nature of human beings, but till the time when he writes Tess of the d'Urbervilles and Jude the Obscure, their nature of advancement has lost, and the reactionary nature of opposing humanity is exposed.

At that time, the popular view on love and marriage is that marriage is a kind of bestowal and prize to those people who obey the social orthodox ideas. It does not permit any inkling of rebellion, or it will regard this way as immoral. And the real meaning of marriage is a contract signed according to law, whether the marriage has the basis in feeling is not a matter of concern. But a divorce means to disobey the management of God, which is regarded as immoral treason and heresy. Hardy is absolutely opposed to the kind of marriage without love. He does not endorse a marriage arising from a sudden impulse, but he does not approve of the matrimonial knot of a male and female with a lawful contract without considering a basis in love. In Tess of the d'Urbervilles and Jude the Obscure, Hardy condemns the sin that capitalism makes the marriage tragedies, attacks the popular marriage view of capitalism of that time, portrays the rebellious figures who are not proper for the society and keep on pursuing the freedom of love and marriage. He expounds his systematic and overall ideal view of love and marriage.

In Tess of the d'Urbervilles, Tess is portrayed with the writer's full attention. Seen from any point of view, Tess is the most perfect and the most successful woman figure in Hardy's gallery of women. He bestows on her every excellent virtue of working people. She is not only strikingly beautiful but kind-hearted, honest, diligent, and thrifty. Furthermore, she loves life very much. Although she is from a poor family and the family life does not bring her happiness, she has very strong feelings for her family. She agrees that she has to assume immense responsibility. In order to maintain the benefits for her family, she would rather sacrifice everything she owns. However, kindness and tolerance are not the whole lot of Tess's character. She is defined by a sexual being. In contrast with this sexuality, Tess possesses certain qualities inherent in males. The thriving passion of Tess serves two purposes in Hardy's novel. In her defiance of the Victorian ideal Tess is empowered and strengthened. This power of passion also results in her isolation from the cruel social environment and ultimately her death.

In the popular dramas and novels of that time, most of the protagonists are males. He works hard for his career of justice, in the end, he is married with an innocent and beautiful girl with good virtue. Hardy does not write novels according to the traditional pattern, he does not tend to use the happy reunion endings, on the contrary, he always ends his stories with tragedy. According to the traditional view, first Tess loses her chastity, then she lives with a male illegally, so she is an indecent and fallen woman. She does not deserve to get mercy and should be punished by God. But Hardy regards her as a pure woman with deep sympathy, which is a brave protest and satire to the social morality of that time. Tess is beautiful, sexual, kind and tolerant, and the most important thing is, her independence and strength separate Hardy's heroines from Victorian heroines. The combination of sexuality and masculine qualities in Hardy's passionate heroines exemplifies a new characterization of women. By the love tragedy of this glittering figure and her miserable ordeal, Hardy mercilessly criticizes the hypocritical law, morality, religion and marriage system which kill the nature of human beings in the capitalist world. Because of this rebellion against orthodoxy, his works were fiercely attacked by the public opinions.

Jude the Obscure is the further exploration on the love theme in Tess of the d'urbervilles. When Hardy begins to portray the female figures in Jude the Obscure, he has observed the human nature deeply. He understands their complicated behavior and displays them to the readers without avoiding them as taboo.

Sue is a classic type who is described by Hardy with his full heart. In the forepart of the novel, Hardy portrays her as a figure that has full consciousness of opposition. According to the view of a German critic, Sue is the first female feminist who has been described in novels. Sue, who is naive and innocent falls in love with Jude, but she is obliged to marry Phillotson due to the oppression of the society. After being married, she and Phillotson are seemingly in harmony but actually at variance, and she is unable to get the noble and unsullied love she has been longing for at all. So she tells Phillotson she wants to live with Jude formally, because they can excite each other's sympathy at heart and communicate with each other by feelings. She thinks the love between her and Jude is true love with the communication of heart and soul. Her thought and action represent the tendency of many women's aspiration for liberation and freedom. The union in matrimony between her and Jude is a marriage relationship which conforms to morality, for they have firm 
love basis which is also pursued with enthusiasm. Sue also opposes the view of unequal position between males and females. She thinks females are also entitled to choose males as many as males are, an apparent example is a comparison of the chosen females with a she-ass or a she-goat which we have quoted above. Her opposition also exhibits her longing for the society of having males and females on an equal footing.

After all, Sue is a woman. Although she has the courage to struggle, under the then social background, her power means almost nothing. In the latter part of the novel she is unable to extricate herself from the conventional view of love and marriage, and has to compromise to destiny at last. She longs for getting her satisfaction of self-emotion, which is to enjoy her fine love life with Jude. And also she wishes she has good virtue to fulfill her emotionless marriage obligation. In the end, she has to be trapped into a deep, complicated and difficult position. Although once she follows the direction of her own feeling to unite with Jude, she is unable to storm and capture the fort of the traditional view of love and marriage in her mind. This view is not a simple pattern any more. It has turned into a spirit inside her with flesh and blood. When Sue leaves Jude, she has fulfilled her self-figure of sacrificing her own feeling to defend the lawful marriage relationship. In the innermost of Sue's character, how profound the moral experience of self-fulfillment and self-examination is!

After the rebellious opposition to reality, Sue has to pay the price all that a woman could pay to get the right that a human should have. Sue is totally disappointed with the real world, and what she wishes is only to meet Jude in Heaven, not in Reality. Her extreme despair reminds us of the word Predestination on the wall of the Notre Dame de Paris. In short, from a fighter with a full spirit of struggles to a woman submitting to the convention under the oppression of the society and waiting for the total predestination of the next life, Sue is drowned by the contract marriage of the capitalist class.

\section{Hardy's Consciousness of Tragedy is the Source of His Evolutionary View}

Through the above analysis it could be concluded that Hardy's view of love and marriage has a long course of development. His works during the period of writing his pastoral novels were blended with plenty of tragic factors. However, most of these novels have their endings in a reunion to the satisfaction of all. But since capitalism invades Wessex country, the tragic factors have been strengthened heavily. When Hardy criticizes capitalism that opposes the humanity mercilessly, the tragic factors occupy a pivotal position in Hardy's works. Spanning the writing period of Far from the Madding Crowd to The Return of the Native, Tess of the d'Urbervilles and Jude the Obscure is the time when Hardy gradually sets and consolidates his style of tragedy. Then what is the reason for Hardy to evolve from a romantic poet who sings the praises of the pastoral life into an austere writer who exposes the tragedies of reality? We venture on an attempt to probe into this question in this thesis, and the analysis could also exhibit the reason of the evolution of Hardy's view on love and marriage.

\subsection{The Two factors of Hardy's Evolution}

Marxism explains the development of things by the reason of their contradiction of one another. The interior reason of the contradiction is the basis of the development, and the exterior reason could accelerate this development to come into being. This theory can be used in an attempt analyze the reasoning of Hardy's tragic consciousness. The interior reason is Hardy's natural and sensitive nature which is influenced by what he sees and hears during his adolescence in his homeland. This can be called the factor of Nature. And capitalism is the exterior reason from its destruction of the feudal patriarchy as the new representative of advanced productive power to its thwarting of the development of society as the apologist of the decayed consciousness. This provides a great social background for the change of Hardy's thought. This can be called the factor of Time. The interaction of the interior and exterior reason consequently, promotes the formation of Hardy's tragic consciousness.

\subsection{The Factor of Nature}

Hardy's father was a skillful stone-mason who inherited the technique of stone-masonry from his family. Hardy's mother was from a farmer's family, though. Hardy hardly received any formal education, but his living environment was the soil for the making of an artist. Around Bockhampton there are woodlands and the dark foliage clothes the woods which overshadow plenty of bushes. Wild ponies, fallow deer, lizards and snakes would turn up in the vicinity from time to time. Hardy loves nature, feels its beauty and he is surprised and fascinated at its mystery and horror further. These indelible impressions in his young mind turn into an outstanding feature in his later works.

At Hardy's time, Wessex, a name which stands for the historical geography turns well known. When Hardy edited all of his works into an anthology in 1920's, he entitled them with the general name of Wessex Novels, and defined the range this area belongs to. The main settings including his fourteen novels and more than forty novelettes and short stories are all in this specific area. The undulating grazing land and field, the rugged coasts and harbors, the serene and extensive mansions and gardens, and the honest peasants and simple country accent, etc, are all regarded as the necessary elements which form his works. In Far from the Madding Crowd, compared with the characters and the accidents, the description of the natural view and the conventional custom occupies a rather large proportion. It looks like a collection 
of some artistic illustrations of the landscapes which are portrayed in the language of prose interspersed among the plots of the stories.

The novelist usually not only deals with the natural and geographic environment as the rather independent element in his novels, but also regards them as a protagonist and endows them the nature of soul. Only a writer with a superior power of understanding to decode nature's mystery can portray such a vivid view. The Return of the Native represents the highest level of his portraying view. In this novel, the view and the characters are mixed together as the supplement or the contrast.

In many of the chapters, all kinds of magic and subtle relationship are exhibited between Egdon Heath and the characters. The country natives taking part in the bonfire celebration on the barrow are mixed into a wholeness with the heath; Eustacia, the beauty who pursues freedom with the modern ideal is definitely not proper for the ancient, simple and desolate style of the heath. The reddle man and his van gallop to and fro like a shadow day and night, which adds the mysterious nature of the heath; the serenity of the heath can also calm down the people's restless hearts. There is no one except Hardy among the British novelists who can personify even defy the characters to such an extent.

Human being's cognition of nature is to be divided into two parts -- the perceptual one and the rational one. As an artist, a poet and a novelist, Hardy pays attention to the perceptual cognition more. He stresses to feel life and nature with the power of perceptivity to achieve the communication with nature and understand the mystery of nature. As long as human beings can achieve harmony with nature, when they face the strong power of it, they could conform to it with the potential instinct of themselves to gain its understanding and regard with tenderness. Hardy's sensitive perceptual ability closed bound by nature and his deep experience sharing joys and sorrows with nature make him feel extremely sorry for nature's course of the ten thousand things of creation. On the one hand, he sings the high praises of nature full of life, of the growth of grass and trees; on the other hand, he sighs for the short time of the nature full of life and the quickness of the growth and the decay. Both instances consist of the sad basis of his works. In brief, to mix himself into nature and always notice to communicate with it is the deepest and the most concealed factor to form Hardy's tragic consciousness. This consciousness that is accumulated from the sorrow for nature and life exists together with the connotation of his characteristic. It is an interior nature that can by no means be changed by the environment of time and society.

\subsection{The Factor of Time}

This basis of tragedy causes Hardy portray the fabulous figure like Eustacia who longs for personal liberty and pursues perfect love in a style without any decoration, especially during the time when free enterprise worms itself into Wessex country which causes the conflict with the old tradition in the society. Although Eustacia's tragedy is inevitable, her spirit is encouraged and highly praised by Hardy. However, when time goes into the late 1890's, Britain fell into the decline due to its decayed politics, and also it lost its free and dominant position in commerce and industry due to its depressed economy. During the period, the social discord becomes more and more irreconcilable owing to the changes taking place in Wessex country and elsewhere at the time. The development of the new emerging domestic economy and the decline of the old small-producer economy, the intrusion of the marketable commodity, the collapse of the patriarchal society, etc, have worsened the situation as far as the country economy is concerned. The situation is again aggravated by the surge of the city reserved working forces and by the introduction of the use of new machines. The austere reality hastens the conflict between the traditional life and the moral view of that time. All these tear off the hypocritical mask of civilization and morality of the personal enterprise.

As said above, Hardy was born in a small town in Dorset County and spent most of his life there. The place seems like haven of peace to him, far from the madding crowd, but Hardy's thought and eyesight never move away from the human world from the end of the nineteenth century to the beginning of the twentieth century. As he lives in the environment of the country, he has deeply grieved feelings and understandings about the machine of civilization intruding into the cultivation style in a British country.

Poverty, starvation and death are the tragic symbols in the middle of the Victorian Age. However, the hack writers of that time are doing their utmost to advocate the so-called "optimism" saying that Victorian Age is experiencing their golden era, and that the civilization and morality of the time is invincible. All these trite and beaten allusions make Hardy wake up from his fantasy of the reality and from his view of pastoral life. He deeply realizes it is exactly the alluded civilization that destroys the patriarchal society of British country. Following the evolution of the new society, people's tragedies have also taken place. The reality is tragic and not optimistic, and this is the factor of Time of Hardy's tragic consciousness. From the hidden misery of his life view of the pastoral style, to his criticism, exposure and opposition of this unequal society, this course of development is exactly the one from Far from the Madding Crowd to Tess of the d'Urbervilles until Jude the Obscure. Also, this is the course of evolution of Hardy's view on love and marriage. 


\section{References}

Allingham, Philip V. (2000). "The Initial Publications of Thomas Hardy's Novella" The Thomas Hardy Journal 16,3 (October).

Auerbach, Nina. (1982). Woman and the Demon: The Life of A Victorian Myth. Cambridge: Harvard University Press.

Denvir, Bernard. (1989). The Early Nineteenth Century Art, Design and Society 1789-1852 New York: Longman Group Limited.

Graves, Algernon. (1895). A Dictionary of Artists Who Have Exhibited Works in the Principal London Exhibitions from 1760 to 1893. London: Henry Graves.

Hardy, Thomas. (1986). Far From the Madding Crowd: An Authoritative Text, Backgrounds, Criticism. Ed. Robert C. Schweik. New York: W.W. Norton \& Company.

Harris, Wendell V. (1968). "English Short Fiction in the 19th Century." Studies in Short Fiction 6 (Fall). 